\title{
Physical Exertion, Thermal stress affect the Cognitive Performance on Adolescent Farmers of West Bengal, India
}

\author{
${ }^{1}$ Banibrata Das, ${ }^{2}$ Tirthankar Ghosh
}

${ }^{1}$ Department of Physiology, South Calcutta Girls' College, University of Calcutta, Kolkata, India ${ }^{2}$ Physiology \& Ergonomics Laboratory. Department of Osteopathy, Sri Sri University, Cuttack, Orissa, India

\section{ABSTRACT}

Background: Cognitive ergonomics relates with studies related to knowledge, knowledge acquisition skills and other factors. In the modern days, the workers are exposed to a work, which demands cognitive skill along with physical ability.

Objectives: Aim of the present study is to evaluate the effect of physical exertion along with thermal stress on the cognitive performance among the adolescent farmers through.

Methods: In the present study, cognitive performance was evaluated through physical exertion along with thermal stress among the adolescent farmers. This cross-sectional study was performed during $2017-18$ among the randomly selected 50 male and 50 female adolescent farmers from the various village of Hooghly District at West Bengal, India. Before conducting the study, legal guardian consent was taken. Prior permission and ethical approval was also obtained from local community leaders as well as relevant authorities before commencement of the study. The memory test or cognitive ability test was done by the Immediate Recovery Test. In cognitive ability test, three pictorial cards were prepared having same length; each of the cards had 15 pictorials. Different pictures card was shown to all the subjects for 15 minutes in resting condition. Immediately after 15 minutes all the subjects were asked to recall the pictures within the 3 minutes. Then, evaluation was undertaken in presence of the subjects.

Results: The result of the study shows that the farmers performed strenuous activity by which they do the more error in cognitive function test than control subjects. This may be due to increase in strenuous activity in agricultural sector by increasing the heart rate (physiological stress) which may decrease the cognitive function among the farmers in compare to control subjects.

Conclusion: The study concludes that intense fatigue producing or highly strenuous agricultural activity lead to an increase in the number as well as in the percentage of wrong answers in the cognitive test. On the other hand, moderate type of agricultural results in a decrease in the number as well as in the percentage of wrong answers and there is an improvement in the cognitive performance.

Key words: Adolescent farmer, Cognitive performance, Physical Exertion, Thermal stress;

DOI: https://doi.org/10.3126/ijosh.v8i2.23331

\section{Introduction}

-he relationship between physical exertion human cognitive performances is very complicated. Study of this complex interaction has opened a new era of ergonomics; it is mainly termed as "Cognitive ergonomics". Cognitive ergonomics relates with

\section{Corresponding Author}

Dr. Tirthankar Ghosh, Associate Professor, Physiology \& Ergonomics Laboratory, Department of Osteopathy, Sri Sri University, Cuttack, Orissa, India.

E-mail: tirthag@gmail.com studies related to knowledge, knowledge acquisition skills and other factors. In the modern days, the workers are exposed to a work, which demands cognitive skill along with physical ability. The cognitive development that occurs during childhood and adolescence is essential to a person's health. Several longitudinal studies have reported that cognitive scores assessed in early life were associated with academic achievement $^{1}$ and mental ability ${ }^{2}$. Physical activity is a

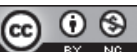

This journal is licensed under a Creative Commons AttributionNon Commercial 4.0 International License. 
theoretically relevant factor that may improve cognitive function from childhood to adulthood. ${ }^{3-5}$ The physical activity and cognitive development study, a longitudinal study to investigate the relationship between physical activity and cognitive development across the human age ranges (from children and adolescents to adults), is intended to provide a holistic platform for the in-depth exploration of these issues. ${ }^{6}$

Hancock and Meshkati stated that physical workload may also affect cognitive task performance. ${ }^{7}$ According to Neerinex the physical workload and time pressure together with the cognitive load create an awful situation for young workers. ${ }^{8}$ Therefore, they may be prone to error, which in turn may lead to production decrease or even accidents. Gutin and Di Gennaro observed a decreased in accuracy in cognitive task of long addition after a physical exertion. ${ }^{9} \mathrm{~A}$ similar positive result was also observed by Reilly and Smith where they performed the test on bicycle ergometer at $85 \%$ VO2 max (maximal oxygen uptake), it affected the cognitive task of simple addition and the result shows an increase in error. ${ }^{10}$

\section{Methods}

In the present study, cognitive performance was evaluated through physical exertion along with thermal stress among the adolescent farmers. This cross-sectional study was performed during $2017-18$ among the randomly selected 50 male and 50 female adolescent farmers from the various village of Hooghly District at West Bengal, India. Before conducting the study, legal guardian consent was taken. Prior permission and ethical approval was also obtained from local community leaders as well as relevant authorities before commencement of the study.

The memory test or cognitive ability test was done by the Immediate Recovery Test. In cognitive ability test, three pictorial cards were prepared having same length; each of the cards had 15 pictorials. Three cards had three different types of pictures. These card pictures are arranged in sequence with the number, all the pictures were same in size and the gaps between the icons were almost equal that was carefully developed to give a clear view of all the items to the subjects.

In cognitive ability test the different pictures card was shown to all the subjects for 15 minutes in resting condition. Immediately after 15 minutes all the subjects were asked to recall the pictures within the 3 minutes. Then, evaluation was undertaken in presence of the subjects. After evaluation, all subjects were asked to performed normal agricultural activities. After 3 hours of work at a stretch, subjects were asked to recall the pictures of the card within 3 minutes. Then second and final evaluation was done in presence of subjects.

\section{Results}

Table 1 represents the physical characteristics of farmers and control subjects. This table shows that there is no statistical significance between the experimental group and control group.

Table 2 shows the association between cognitive test among the farmers in resting condition and just after work along with physiological test in all the agricultural activities. This study stated that among the agricultural activities in potato cultivation, some of the activities like- carrying seeds, spading, sprinkling water, harvesting or picking crops and carrying crops are the activities which have a significant effect in resting condition and just after work. The effects of different sort of strenuous agricultural activities on cognitive ability (Memory test) were also studied. The results (Table 2) shows that intense fatigue producing or highly strenuous agricultural activity (like spading) lead to an increase in the number as well as in the percentage of wrong answers in the memory tests. On the other hand, moderate type of agricultural activities (i.e. less fatiguing activity- like carrying seeds, crops etc.) resulted in a decrease in the number as well as in the percentage of wrong answers and there is an improvement in the cognitive performance.

Table 3 shows the association between cognitive test among the farmers and control subjects in just after work. The result of the study showed that after the spading, sprinkling water, carrying seeds, harvesting or picking crops and carrying crops are the agricultural activities in which farmers and the control subjects have a significant effect.

Table 4 indicates that there was no significant difference in cognitive test in between male and female adolescent farmers in different agricultural activities in potato cultivation (except- carrying seeds activity and spading activity).

Table 5 shows the association between cognitive tests in related with thermal stress among adolescent farmers. This table shows there is no statistical change in cognitive performance between male and female adolescent farmers in different thermal environment. 
COGNITIVE ABILITY TEST

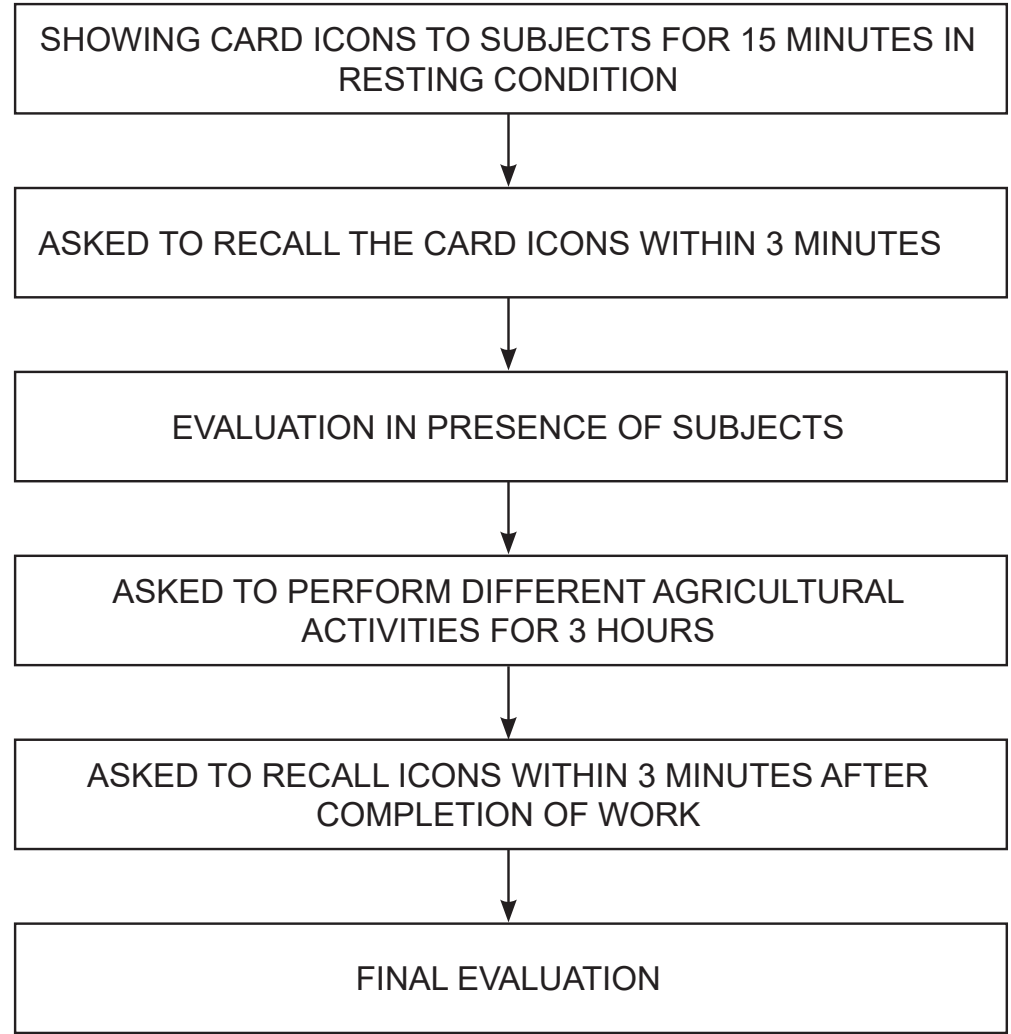

Table 1: Physical Characteristics of farmers and control subjects

\begin{tabular}{|c|c|c|c|c|}
\hline Parameters & Farmers & Control subjects & t value & $P$ value \\
\hline Age & $18.0 \pm 0.82$ & $18.2 \pm 0.85$ & 1.76 & 0.085 \\
\hline Height & $167.63 \pm 5.85$ & $168.16 \pm 5.20$ & 0.747 & 0.456 \\
\hline Weight & $58.75 \pm 9.10$ & $58.35 \pm 6.82$ & 0.362 & 0.717 \\
\hline BMI & $20.98 \pm 8.22$ & \pm 7.32 & 0.270 & 0.787 \\
\hline
\end{tabular}

Table 2: Association between cognitive test among the farmers in resting condition and just after work condition along with physiological test

\begin{tabular}{|c|c|c|c|c|c|c|c|c|}
\hline \multicolumn{3}{|c|}{ Resting condition } & \multirow{3}{*}{$\begin{array}{c}\text { Different } \\
\text { Agriculture } \\
\text { Activity }\end{array}$} & \multirow[b]{3}{*}{$\begin{array}{l}\text { Duration } \\
\text { of work }\end{array}$} & \multicolumn{3}{|c|}{ Just After Work } & \multirow[b]{3}{*}{$P$ value } \\
\hline \multirow{2}{*}{$\begin{array}{l}\text { Average } \\
\text { Heart rate } \\
\text { beats/ min }\end{array}$} & \multicolumn{2}{|c|}{ Cognitive Test } & & & \multirow{2}{*}{$\begin{array}{l}\text { Average } \\
\text { Heart rate } \\
\text { beats/ min }\end{array}$} & \multicolumn{2}{|c|}{ Cognitive Test } & \\
\hline & $\begin{array}{l}\text { No. of } \\
\text { Correct } \\
\text { Answer }\end{array}$ & $\begin{array}{l}\text { No. of } \\
\text { Wrong } \\
\text { Answer }\end{array}$ & & & & $\begin{array}{l}\text { No. of } \\
\text { Correct } \\
\text { Answer }\end{array}$ & $\begin{array}{l}\text { No. of } \\
\text { Wrong } \\
\text { Answer }\end{array}$ & \\
\hline 76.2 & 15 & 00 & Weeding & $48.7 \mathrm{~min}$ & 118.8 & 11 & 04 & 0.107 \\
\hline 77.8 & 15 & 00 & Ridging & $112.6 \mathrm{~min}$ & 115.9 & 12 & 03 & 0.224 \\
\hline 75.5 & 15 & 00 & Carrying seeds & $66.2 \mathrm{~min}$ & 122.8 & 10 & 05 & 0.050 \\
\hline 76.8 & 14 & 01 & Planting seeds & $78.5 \mathrm{~min}$ & 132.5 & 09 & 06 & 0.084 \\
\hline 76.2 & 14 & 01 & Spading & $85.5 \mathrm{~min}$ & 152.6 & 06 & 09 & 0.007 \\
\hline 75.8 & 15 & 00 & Sprinkling water & $52.6 \mathrm{~min}$ & 122.4 & 07 & 08 & 0.017 \\
\hline 76.7 & 15 & 00 & Picking up crops & $118.7 \mathrm{~min}$ & 132.8 & 09 & 06 & 0.084 \\
\hline 75.9 & 14 & 01 & Carrying crops & $58.2 \mathrm{~min}$ & 124.7 & 08 & 07 & 0.039 \\
\hline
\end{tabular}


Table 3. Association between cognitive test among the farmers and control subjects in just after work condition.

\begin{tabular}{|c|c|c|c|c|c|c|c|c|c|}
\hline \multirow[b]{3}{*}{$\begin{array}{l}\text { Agricultural } \\
\text { activity }\end{array}$} & \multirow[b]{3}{*}{$\begin{array}{l}\text { Duration } \\
\text { of work }\end{array}$} & \multicolumn{3}{|c|}{ Farmers } & \multirow[b]{3}{*}{$\begin{array}{l}\text { Duration } \\
\text { of work }\end{array}$} & \multicolumn{3}{|c|}{ Control subjects } & \multirow[b]{3}{*}{$\begin{array}{c}P \\
\text { value }\end{array}$} \\
\hline & & \multirow{2}{*}{$\begin{array}{c}\text { Just after } \\
\text { work } \\
\text { Heart rate } \\
\text { beats/min }\end{array}$} & \multicolumn{2}{|c|}{ Cognitive Test } & & \multirow{2}{*}{$\begin{array}{c}\text { Just after } \\
\text { work } \\
\text { Heart rate } \\
\text { beats/min }\end{array}$} & \multicolumn{2}{|c|}{ Cognitive Test } & \\
\hline & & & $\begin{array}{l}\text { No. of } \\
\text { Correct } \\
\text { Answer }\end{array}$ & $\begin{array}{l}\text { No. of } \\
\text { Wrong } \\
\text { Answer }\end{array}$ & & & $\begin{array}{l}\text { No. of } \\
\text { Correct } \\
\text { Answer }\end{array}$ & $\begin{array}{l}\text { No. of } \\
\text { Wrong } \\
\text { Answer }\end{array}$ & \\
\hline Weeding & $48.7 \mathrm{~min}$ & 118.8 & 11 & 04 & $180.2 \min$ & 104.8 & 14 & 01 & 0.327 \\
\hline Ridging & $112.6 \mathrm{~min}$ & 115.9 & 12 & 03 & & & & & 0.591 \\
\hline Carrying seeds & $66.2 \mathrm{~min}$ & 122.8 & 10 & 05 & & & & & 0.171 \\
\hline Planting seeds & $78.5 \mathrm{~min}$ & 132.5 & 09 & 06 & & & & & 0.084 \\
\hline Spading & $85.5 \mathrm{~min}$ & 152.6 & 06 & 09 & & & & & 0.007 \\
\hline Sprinkling water & $52.6 \mathrm{~min}$ & 122.4 & 07 & 08 & & & & & 0.017 \\
\hline Picking up crops & $118.7 \mathrm{~min}$ & 132.8 & 09 & 06 & & & & & 0.084 \\
\hline Carrying crops & $58.2 \mathrm{~min}$ & 124.7 & 08 & 07 & & & & & 0.039 \\
\hline
\end{tabular}

Table 4: Association between male \& female farmers after different agricultural activity of cognitive test

\begin{tabular}{|c|c|c|c|}
\hline Activity & Sex & $\gamma 2$ & Remarks $P<0.05$ \\
\hline Resting & $\begin{array}{l}\text { Male } \\
\text { Female }\end{array}$ & 1.17 & Not significant \\
\hline Weeding & $\begin{array}{l}\text { Male } \\
\text { Female }\end{array}$ & 0.58 & Not significant \\
\hline Ridging & $\begin{array}{l}\text { Male } \\
\text { Female }\end{array}$ & 1.00 & Not significant \\
\hline Carrying seeds & $\begin{array}{l}\text { Male } \\
\text { Female }\end{array}$ & 8.21 & Significant \\
\hline Planting seeds & $\begin{array}{l}\text { Male } \\
\text { Female }\end{array}$ & 0.14 & Not significant \\
\hline Spading & $\begin{array}{l}\text { Male } \\
\text { Female }\end{array}$ & 8.14 & Significant \\
\hline Sprikling water & $\begin{array}{l}\text { Male } \\
\text { Female }\end{array}$ & 0.27 & Not significant \\
\hline Picking up crops & $\begin{array}{l}\text { Male } \\
\text { Female }\end{array}$ & 0.15 & Not significant \\
\hline Carrying crops & $\begin{array}{l}\text { Male } \\
\text { Female }\end{array}$ & 0.11 & Not significant \\
\hline
\end{tabular}

Table 5: Assessment of cognitive test (memory test) in different seasonal temperature among male and female farmers

\begin{tabular}{|c|c|c|c|c|c|c|c|c|}
\hline \multirow[b]{3}{*}{ Seasons } & \multirow[b]{3}{*}{$\begin{array}{l}\text { Dry Bulb } \\
\qquad\left({ }^{\circ} \mathrm{C}\right)\end{array}$} & \multirow[b]{3}{*}{$\begin{array}{l}\text { Wet Bulb } \\
\qquad\left({ }^{\circ} \mathrm{C}\right)\end{array}$} & \multirow[b]{3}{*}{$\begin{array}{c}\text { WBGT } \\
\left({ }^{\circ} \mathrm{C}\right)\end{array}$} & \multicolumn{4}{|c|}{ Cognitive Test } & \multirow[b]{3}{*}{$P$ value } \\
\hline & & & & \multicolumn{2}{|c|}{ Male farmers } & \multicolumn{2}{|c|}{ Female farmers } & \\
\hline & & & & $\begin{array}{c}\text { Average } \\
\text { No. of } \\
\text { Correct } \\
\text { Answer }\end{array}$ & $\begin{array}{c}\text { Average } \\
\text { No. of } \\
\text { Wrong } \\
\text { Answer }\end{array}$ & $\begin{array}{c}\text { Average } \\
\text { No. of } \\
\text { Correct } \\
\text { Answer }\end{array}$ & $\begin{array}{c}\text { Average No. } \\
\text { of Wrong } \\
\text { Answer }\end{array}$ & \\
\hline Winter & $26.5 \pm 2.42$ & $22.4 \pm 2.26$ & $25.8 \pm 1.88$ & 12 & 03 & 10 & 05 & 0.680 \\
\hline Spring & $30.2 \pm 2.24$ & $25.9 \pm 2.58$ & $27.2 \pm 1.86$ & 11 & 04 & 08 & 07 & 0.449 \\
\hline Summer & $38.9 \pm 3.20$ & $35.6 \pm 2.45$ & $37.0 \pm 1.88$ & 08 & 07 & 06 & 09 & 0.714 \\
\hline
\end{tabular}

\section{Discussion}

Memory refers to the capability of the neurons to recreate the same spatial and temporal pattern of stimulation of a future date; memory is the process by which the acquisition of information as a result of learning is stored and retrieved. The memory can be divided into non-declarative and declarative memory. The declarative memory in human is divided into 1) 
working memory, short term or recent memory \& 2) remote memory or long-term memory. ${ }^{11}$ Short-term memory is the recalling of events, which have occurred, seconds to hours or even days.

The corrected effective temperature (CET) at the work sites remained above the recommended value $\left(28.5^{\circ} \mathrm{C}\right)$ for heavy types of work as suggested by World Health Organization (WHO). ${ }^{12}$ It was earlier indicated that actions to avert the risk of heat strain are particularly required when CET is over $27.9^{\circ} \mathrm{C}$ $13^{-15}$ as a high level of physical effort since this level of thermal exposure could have a harmful impact on the health of the workers. ${ }^{16}$ These thermally stressful situations do have a negative influence on workplace safety ${ }^{17}$ In these study, it was found that the farmers were exposed to high thermal stress in summer time. As result the farmers failed in cognitive test (memory test) in summer, in comparison to the other seasonal temperature (Table 5)

The heart rate just after the completion of work of the farmers is significantly high due to constant movement of the body. The present findings are supported by the findings of Guyton ${ }^{11}$, who also emphasized that stretching of muscles caused vasoconstriction in the muscles which resulted in restriction of blood flow and in turn increased the cardiorespiratory stress. This study stated that among the different agricultural, which have a significant effect in resting condition and just after work. The effects of different sort of strenuous agricultural activities on cognitive ability (Memory test) were also affected. The study found that intense fatigue producing or highly strenuous agricultural activity lead to an increase in the number / percentage of wrong answers in the memory tests. On the other hand, moderate type of agricultural activities resulted in a decrease in the number as well as in the percentage of wrong answers and there is an improvement in the cognitive performance.

The result of the study shows that the farmers performed strenuous activity by which they do the more error in cognitive function test than control subjects. This may be due to increase in strenuous activity in agricultural sector by increasing the heart rate (physiological stress) which may decrease the cognitive function among the farmers in compare to control subjects. This study also observed that, highly strenuous agricultural activity (spading and planting seeds) lead to an increase in the percentage of wrong answers in the memory test in compare to other agricultural activities in potato farming. The other agricultural activities also give the same result in case of both male and female experimental subjects. So it can be said that physical exertion or activity may lead to decrease in cognitive function in case of both male and female experimental subjects, that means, due to physical exertion or activity, the wrong number of answer were significantly increased during the just after work condition or during post exercise or activity memory test than the resting condition or pre-exercise memory test.

A possible explanation for that impairment of memory is that the cerebral sympathetic stimulation becomes activated strongly during the increase of blood pressure to constrict the cerebral arteries markedly; when the arterial pressure rises to a very high level during strenuous exercise or activity due to excessive circulatory activity, the sympathetic nervous system constrict the large and intermediate sized arteries and prevents the high pressure from ever reaching the smaller blood vessels to prevent the occurrence of stroke. ${ }^{11}$ That may lead to short supply of blood to different region of brain. But the neurons have a very high metabolic rate, so far more energy is required by each brain cell than other cells of the body tissues and the amount of glycogen stored in neuron is very slight amount which accounts to only 02 mins of supply of glucose. ${ }^{11}$ That short supply of blood together with less glucose concentration of that blood and high metabolic rate of brain cells may lead to "Shut off" of some of the sympathetic activity of neuron in order to maintain the other function. In this experiment, the awkward posture and heavy muscular activity (motor function) were the main function during exercise and to maintain those functions, brain might have "Shut off" the memory function that might lead to the impairment of cognitive function during post exercise or activity memory test.

\section{Conclusion}

The relationship between physical exertion and human cognitive performance is very common. The result of the study clearly shows that the number of wrong response in cognitive test significantly increases during the post farming activity than the pre farming activities. This study also concludes that the thermal stress may decrease the cognitive function among the farmers. This study also shows in hot and humid condition (summer), the cognitive performance of the both group of farmers decreases.

The result of the study concludes that intense fatigue 
producing or highly strenuous agricultural activity (like spading) lead to an increase in the number as well as in the percentage of wrong answers in the cognitive test. On the other hand, moderate type of agricultural activities (i.e. less fatiguing activity- like carrying seeds, crops etc.) results in decrease in the number as well as in the percentage of wrong answers and there is an improvement in the cognitive performance.

The result of the study concludes that the farmers performed strenuous activity by which they do the more error in cognitive function test than control subjects. This may be due to increase in strenuous activity in agricultural sector by increasing the heart rate (physiological stress) which may decrease the cognitive function among the farmers in compare to control subjects.

\section{Acknowledgement}

The authors express their sincere gratitude to all those workers who rendered immense co-operation towards completion of this study.

\section{References}

1. Geary DC. Cognitive predictors of achievement growth in mathematics: A 5-year longitudinal study. Developmental Psychology. 2011;47(6):153952.

2. Deary IJ, Whalley LJ, Lemmon H, Crawford JR, Starr JM. The stability of individual differences in mental ability from childhood to old age: Follow-up of the 1932 Scottish mental survey. Intelligence. 2000;28(1):49-55.

3. Haapala E. Physical Activity, Academic Performance and Cognition in Children and Adolescents. A Systematic Review. Baltic Journal of Health and Physical Activity. 2012;4(1):53-61.

4. Morales J, Gonz A LISA, Lez M, Virgili C, Unnithan V., Physical activity, perceptual-motor performance, and academic learning in 9-to-16-years-old school children. Int J Sport Psychol. 2011;42:401-15.

5. Esteban-Cornejo I, Tejero-Gonzalez CM, Sallis JF, Veiga OL. Physical activity and cognition in adolescents: A systematic review. Journal of Science and Medicine in Sport. 2015;1(5):534-39.

6. Zhao G, Quan M, Su L, Zhang H, Zhang J, Zhang J. Effect of Physical Activity on Cognitive Development: Protocol for a 15-Year Longitudinal Follow-Up Study. BioMed Research International. 2017;2017:7 pages. Article ID 8568459. DOI: https://doi. org/10.1155/2017/8568459.

7. Hart SG, Staveland LE. Development of NASATLX (Task Load Index): Results of Empirical and Theoretical Research. In: Handcock PA, Meshkati N, Editors. Human Mental Workload. North-Holland: Elseviere Science Publishers BV; 1998. pp. 139-83.

8. Neerinex AM. Cognitive task analysis: Harmonizing task is to human capacities. Ergonomics. 1996;39(4):543-61.

9. Gutin B, Di Gennaro J. Effect of treadmill run to exhaustion on performance of simple addition. Research Quaterly. 1968;39:958-64.

10. Reilly $T$, Smith $D$. Influece of metabolic loading on a cognitive task. In: Megaw ED, ed. Contemporary Ergonomics. London: Taylor and Francis; 1984. pp.104-09.

11. Guyton AC. Text Book of Medical Physiology. $9^{\text {th }}$ edition. Philadelphia: WB Saunders Company; 1991. Pp.362-365.

12. World Health Organization. Health factors in working under conditions of heat stress. WHO Tech Rep Series. Geneva:WHO; 1996:412.

13. Saha R, Dey NC, Samanta A, Biswas R. AComparison of Cardiac strain among drillers of two different age groups in underground manual coal mines in India. J Occup Health. 2008;50:512 - 20.

14. Hanson MA, Cowie HA, George JPK, Graham MK, Graveling RA, Hutchinson PA. Physiological Monitoring of Heat stress in UK of coalmines. IOM Research Report. 2000;TM00/05.

15. Pickering AJ, Tuck MA. Heat sources, evaluation, determination of heat stress, and heat stress treatment. Mining technology Trans I Min E. 1997;79:147-56.

16. Kulagowska E. Physical cost of working under conditions of thermal load. Med Pr. 1997;48:265-71.

17. Ramsey J, Burford C, Beshir M, Jensen R. Effects of workplace thermal conditions on safe work behavior. J Safety Research 1983;14:105-14. 